\title{
PENGARUH PEMBERIAN PUPUK MAJEMUK NPK DAN LIMBAH CAIR TAHU TERHADAP PERTUMBUHAN BAWANG MERAH (Allium asaclonicum. L)
}

\author{
Markus Kola Raga, Novi Ivonne Bullu, Sonya Titin Nge \\ Corresponden author : Novi_bullu@gmail.com \\ Program Studi Pendidikan Biologi, Fakultas Keguruan dan Ilmu Pendidikan, Universitas Kristen Artha \\ Wacana Kupang- NTT
}

\begin{abstract}
ABSTRAK
Bawang merah (Allium ascalonicum L.) merupakan komoditas tanaman horikultura yang banyak dikonsumsi oleh masyarakat sebagai bumbu masakan dan memiliki nilai ekonomis yang tinggi dipasaran. berdasarkan hasil observasi peneliti dikebun pertanian yang ada di Desa Mata Air, bawang merah mengalami masalah pertumbuhan. Oleh karena itu penulis melakukan penelitian ini. Dengan demikian tujuan penelitian ini untuk mengetahui pengaruh pemberian pupuk NPK dan limbah cair tahu serta kosentrasi yang paling efektif yang meningkatkan pertumbuhan bawang merah. Penelitian ini telah dilaksanakan didesa Mata Air Tarus Kabupaten Kupang selama 3 bulan. Jenis pendekatan penelitian yang digunakan dalam penelitian ini yaitu penelitian eksperimen dengan desain RAK dengan 12 unit percobaan yakni: satu kontrol dan sebelas perlakuan. Parameter tanaman yang diamati meliputi jumlah daun, tinggi tanaman dan diameter umbi. Data dianalisis secara statistik menggunakan ANOVA satu jalur dengan taraf signifikansi 5\%. Hasilnya menunjukan Konsentrasi perlakuan yang dapat meningkatkan parameter pertumbuhan jumlah daun, tinggi tanaman, jumlah umbi dan diameter umbi bawang merah yaitu pada perlakuan $\mathrm{P}_{1}-\mathrm{P}_{3}$, dengan konsentrasi perlakuan yang paling optimal dalam meningkatkan parameter jumlah umbi bawang merah adalah konsentrasi $50 \%$ pupuk NPK $+50 \%$ limbah cair tahu. Akan tetapi, pengaruh pemberian pupuk NPK dan limbah cair tahu dengan kosentrasi lebih rendah dan lebih tinggi dapat menunjukan hasil yang kurang optimal.
\end{abstract}

Kata Kunci: Bawang Merah, (Allium ascalonicum L.), Pupuk NPK dan Limbah Tahu

\begin{abstract}
Red onion (Allium ascalonicum L.) is a medicinal plant commodity that is widely consumed by the public as a spice and has high economic value in the market. based on observations of researchers at the agricultural plantations in Mata Air Village, shallots experience growth problems. Therefore the authors conducted this study. Thus the purpose of this study was to determine the effect of giving NPK fertilizer and tofu liquid waste as well as the most effective concentrations that increase the growth of shallots. This research was conducted in the village of Tarus Spring in Kupang Regency for 3 months. The type of research approach used in this study is experimental research with RAK design with 12 experimental units namely: one control and eleven treatments. Plant parameters observed included the number of leaves, plant height and tuber diameter. Data were analyzed statistically using one-way ANOVA with a significance level of $5 \%$. The results showed a concentration of treatment that could increase the parameters of growth in number of leaves, plant height, number of tubers and shallot tuber diameter, in treatment P1-P3, with the most optimal concentration in increasing the parameters of the number of onion bulbs was $50 \%$ concentration of NPK +50 fertilizer $\%$ tofu liquid waste. However, the effect of giving NPK fertilizer and tofu liquid waste with lower and higher concentrations can show less optimal results.
\end{abstract}

Keywords: Red Onion, (Allium ascalonicum L.), NPK Fertilizer and Tofu Waste 
PENDAHULUAN

\section{Jurnal pendidikan dan Sains Biologi \\ Volume 1(3) 2018 (24-33)}

Bawang merah (Allium ascalonicum L.) merupakan komoditas tanaman horikultura yang banyak dikonsumsi oleh masyarakat sebagai bumbu masakan, bawang merah memiliki nilai ekonomis yang tinggi dipasaran. Dalam pertumbuhan dan perkembangan tanaman, kususnya bawang merah sangat dipengaruhi oleh pemberian dan ketersediaan unsur hara didalam tanah, untuk mencapai pertumbuhan yang optimal seluruh unsur hara harus berada dalam keadaan seimbang. Peneliti melakukan observasi dikebun pertanian yang ada di Desa Mata Air, bawang merah pemilik petani didesa tersebut mengalami masalah dengan pertumbuhan vegetatif yakni bawang merah mengalami pertumbuhan kerdil dan daunnya berwarna hijau kekuningan. Sehubungan dengan permasalah tersebut diperkuat dengan pendapat Hidayat dan Rosliana, (1996). Dalam Saputra, E. P, (2016). Pemberian pupuk secara optimal dapat mempengaruhi pertumbuhan tanaman. Unsur hara makro utama yang mempengaruhi hasil dan kualitas bawang merah adalah N, P dan K. Unsur hara ini dibutuhkan lebih banyak karena tanaman sering mengalami defisiensi unsur hara tersebut. Lebih lanjut menurut Hasibuan (2004) dalam Saputra E. P, (2016), menyatakan bahwa Pupuk majemuk NPK umumnya kurang efektif dalam menunjang pertumbuhan tanaman, karna unsur N, P dan $\mathrm{K}$ sering mengalami proses pencucian, penguapan dan tererosi sehingga unsur hara semakin berkurang. Oleh sebab itu, bawang merah membutuhkan penambahan hara dari luar untuk dapat hidup optimal. Menurut Savci, (2012) dalam setiwan. A, dkk (2015). Penggunaan pupuk anorganik sangat efektif dalam meningkatkan produksi tanaman tetapi pupuk anorganik dengan penggunaan yang berlebihan dapat menyebabkan pembusukan buah tanaman dan polusi perairan, untuk mengatasi hal tersebut diatas maka salah satu upaya yang dapat dilakukan adalah dengan penambahan pupuk organik. Namun demikian kendala yang dihadapi dalam pemakaian pupuk organik adalah jumlahnya yang terbatas sehingga diperlukan sumbersumber lain. Salah satu sumber bahan organik yang mempunyai potensi besar untuk digunakan sebagai pupuk organik alternatif adalah limbah cair tahu.

Berdasarkan penelitian-penelitian terdahulu, limbah cair tahu mengandung unsur-unsur yang dibutuhkan tanaman. Fatha (2007) melaporkan bahwa limbah cair tahu mengandung bahan organik yaitu karbohidrat dengan kadar $0,11 \%$, protein dengan kadar $0,42 \%$, lemak dengan kadar $0,13 \%$, besi dengan kadar $4,55 \%$, fosfor dengan kadar $1,74 \%$ serta air dengan kadar 98,8\%. Menurut Rosallina (2008) dalam Jong. Y (2016) menjelaskan bahwa limbah tahu memiliki kandungan organik tinggi serta apabila protein yang terkandung dalam limbah cair tahu diurai oleh mikroba tanah maka senyawa $\mathrm{N}$ dapat dilepaskan dan diserap oleh akar tanaman. Karena itu, limbah tahu berpotensi untuk meningkatkan pertumbuhan tanaman budidaya. Berdasarkan uraian diatas peneliti ingin melakukan penelitian dengan judul Pengaruh Pemberian Pupuk Majemuk NPK Dan Limbah Cair Tahu Terhadap Pertumbuhan Bawang Merah (Allium ascalonicum L.)

\section{Tempat dan waktu Penelitian}

\section{METODE PENELITIAN}

Penelitian ini telah dilaksanakan di Desa Mata Air Tarus, Kecamatan Kupang Timur, Kabupaten Kupang, sedangkan limbah cair tahu yang digunakan diambil dari pabrik Tahu yang berada di Kelurahan Bakunase Kota Kupang. Penelitian ini telah dilakukan pada bulan September-November 2017.

Alat dan Bahan

Alat yang digunakan untuk penelitian ini yaitu cangkul, polibag, kertas label, gelas ukur $100 \mathrm{ml}$, Meter roll $(\mathrm{cm})$, timbangan analiitik dan alat tulis. Bahan yang digunakan pada penelitian ini antara lain pupuk majemuk NPK limbah cair tahu yang diambil dari pabrik tahu di Kelurahan Bakunase, bawang merah (Allium ascalonicum L.) dan air sumur. 


\section{Indigenous Biologi \\ Jurnal pendidikan dan Sains Biologi \\ Volume 1(3) 2018 (24-33)}

\section{Rancangan Penelitian}

Jenis pendekatan yang digunakan dalam penelitian ini yaitu rancangan acak kelompok (RAK) yang terdiri dari tiga faktor.

1. Faktor kombinasi pupuk majemuk NPK dan limbah cair tahu, terdiri dari tiga taraf $\mathrm{P}_{1}=25 \%$ Pupuk NPK $+75 \%$ Limbah cair tahu P2 $=50 \%$ Pupuk NPK $+50 \%$ Limbah cair tahu $\mathrm{P}_{3}=75 \%$ Pupuk NPK $+25 \%$ Limbah cair tahu

2. Faktor pupuk majemuk NPK P4 $=25 \%$ Pupuk NPK

$P 5=50 \%$ Pupuk NPK

P6 $=75 \%$ Pupuk NPK P7 $=100 \%$ Pupuk NPK

3. Faktor limbah cair tahu

$\mathrm{P} 8=25 \%$ Limbah cair tahu P9 $=50 \%$ Limbah cair tahu $\mathrm{P} 10=75 \%$

Limbah cair tahu P11 = 100\% Limbah cair tahu

\section{Prosedur penelitian}

1. Persiapkan lahan

Tanah dicangkul lalu dihancurkan dan diisi kedalam polibag dengan ukuran $15 \times 15 \mathrm{~cm}$ yang sudah di sediakan.

2. Persiapan Benih

Sebelum bawang ditanam kedalam polibag yang sudah disiapkan langkah awal yang dilakukan yaitu:

a. Pemilihan buah atau siung bawang merah

Umbi bawang merah yang digunakan dalam penelitian ini harus sama oleh karna itu terlebih dahulu diukur diameter umbinya dengan menggunakan meter $(\mathrm{cm})$

b. Pemotongan

Umbi bawang merah yang telah dipilih, terlebih dahulu di potong ujung umbinya, lalu disimpan di tempat yang tidak terpancarkan oleh cahaya matahari selama 2 hari, pemotongan ujung siung bawang ini juga bertujuan agar bawang dapat tumbuh tunas secara merata

3. Penanaman

Sebelum bawang merah ditanam terlebih dahulu lahan yang sudah disiapkan disiram dengan air hingga tanah tersebut benar-benar basah, setiap polibag akan ditanam sebayak dua siung per polibag.

4. Penyiraman

Penyiraman dengan air biasa dilakukan dengan secukupnya dengan melihat tingkat kelembapan dan kekeringan permukaan tanah tersebut.

5. Pemberian pupuk majemuk NPK

Aplikasi dengan pupuk NPK sebayak satu kali yaitu ketika bawang merah sudah berumur satu minggu setelah tanam (7 HST), aplikasi pupuk majemuk NPK ini dengan cara menunggal pupuk disekitar tanaman

6. Pemberian Limbah Cair Tahu

Pemberian Limbah cair tahu sebanyak empat kali ( 4x ) yaitu ketika bawang merah berumur 7 HST, 14 HST, 21 HST dan 28 HST.

7. Pemeliharaan

Pemeliharaan rutin yang dilakukan meliputi penyiraman, pegemburan tanah dan membersihkan rumput pada petak percobaan. Sedangkan pengendalian hama dan penyakit dilakukan bila diperlukan dengan menggunakan Asakarida.

8. Panen dan pasca panen

Umbi bawang merah dapat dipanen setelah paling sedikit $90 \%$ daun bagian atas rebah. Panen dilakukan dengan cara mencabut tanama secara hati-hati agar umbinya tidak rusak atau tertinggal. Umbi yang telah dipanen, dibersihkan kemudian dikeringkan. Pengeringan umbi 


\section{Indigenous Biologi \\ Jurnal pendidikan dan Sains Biologi \\ Volume 1(3) 2018 (24-33)}

dilakukan dengan cara dijemur selama kurang lebih 3 hari sampai daun bawang benarbenar kering.

\section{Parameter}

Dalam penelitian ini akan dilakukan pengamatan sebanyak lima kali (5x) yakni satu minggu setelah tanam, dua minggu setelah tanam, tiga minggu setelah tanam, empat minggu setelah tanam dan lima minggu setelah tanam. Perubahan yang akan di amati meliputi :

a. Jumlah daun

Perhitungan jumlah daun dilakukan sejak satu mingu setelah tanam sampai lima minggu setelah tanam.

b. Tinggi Tanaman ( $\mathrm{cm}$ )

Tinggi tanaman diukur sejak satu minggu setelah tanam sampai lima minggu setelah tanam. Tanaman diukur mulai dari atas permukaan tanah hingga titik tumbuh tanaman.

c. Jumlah umbi

Jumlah umbi dihitung setelah bawang di panen, perhitungan jumlah umbi ini dilakukakan perrumpun atau persampel.

d. Diameter buah atau umbi

Umbi sampel setelah dibersihkan dari tanah selanjutnya diukur diameter dengan cara mengukur pada bagian tengah buah bawang yang telah dipilih dari setiap taraf perlakuan

\section{Analisis Data} sebanyak satu umbi yaitu umbi yang terbesar (TB)

Data hasil pengamatan dianalisis secara statistik menggunakan analisis variansi (ANOVA) satu jalur dengan taraf signifikansi 5\%. Analisis statistik dilakukan dengan menggunakan program SPSS

\section{HASIL DAN PEMBAHASAN}

Pengaruh pupuk NPK dan Limbah Tahu terhadap Jumlah daun dan Tinggi Bawang Merah

Berdasarkan hasil penelitian yang telah dilakukan untuk mengetahui pengaruh pemberian pupuk NPK dan Limbah cair tahu terhadap pertumbuhan tanaman bawang merah ( Allium ascalonicum. L ) adalah data tentang jumlah daun, tinggi tanaman, jumlah umbi dan diameter umbi. Data-data tersebut di kumpulkan melalui pengukuran jumlah daun dan tinggi tanaman yang dilakukan pada waktu 7 HST-28 HST, sedangkan jumlah umbi dan diameter umbi di ukur setelah bawang di panen. Terkait dengan data penelitian tersebut akan dijelaskan Tabel 1 berikut :

Tabel 1 Rata-Rata Jumlah Daun Dan Tinggi Tanaman Bawang Merah Berumur Lima Minggu

\begin{tabular}{cccc}
\hline Perlakuan & N & $\begin{array}{c}\text { Jumlah } \\
\text { Daun }\end{array}$ & $\begin{array}{c}\text { Tinggi } \\
\text { Tanaman }\end{array}$ \\
\hline $\mathrm{K}$ & 3 & 18 & 26,66 \\
\hline $\mathrm{P} 1$ & 3 & 22 & 34,66 \\
\hline $\mathrm{P} 2$ & 3 & 27 & 38,66 \\
\hline $\mathrm{P} 3$ & 3 & 22 & 35 \\
\hline $\mathrm{P} 4$ & 3 & 19 & 32 \\
\hline $\mathrm{P} 5$ & 3 & 21 & 34 \\
\hline $\mathrm{P} 6$ & 3 & 20 & 33 \\
\hline $\mathrm{P} 7$ & 3 & 19 & 32,33 \\
\hline $\mathrm{P} 8$ & 3 & 19 & 32 \\
\hline $\mathrm{P} 9$ & 3 & 21 & 34 \\
\hline $\mathrm{P} 10$ & 3 & 20 & 33 \\
\hline $\mathrm{P} 11$ & 3 & 20 & 32,66 \\
\hline
\end{tabular}




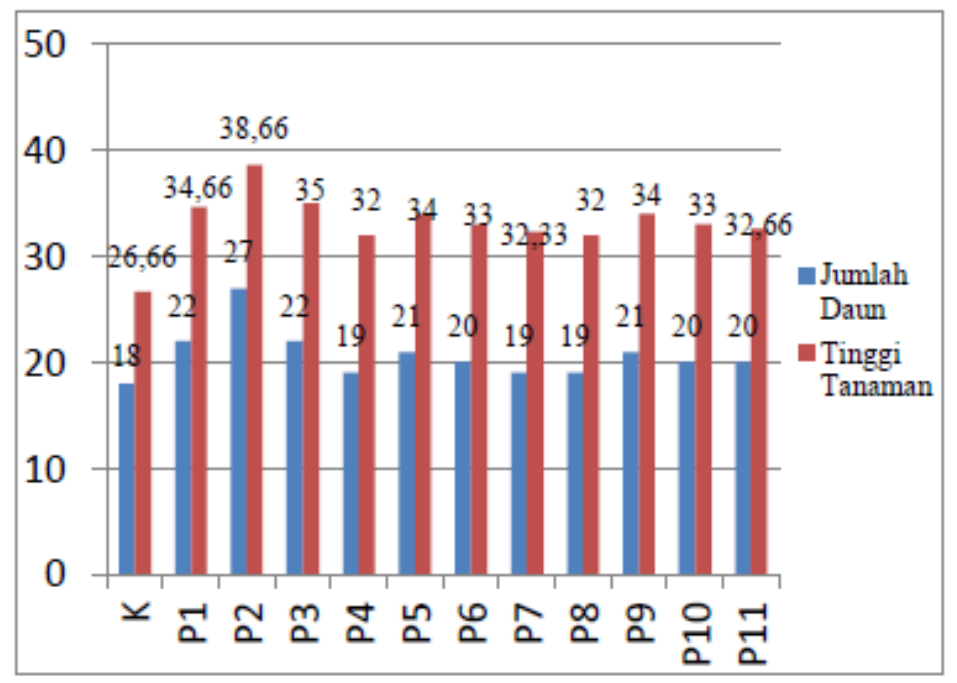

Gambar 1. Rata-Rata Jumlah Daun Dan Tinggi Tanaman Bawang Merah Berumur Lima Minggu

Ringkasan Hasil uji Anova data jumlah daun dan tinggi tanaman bawang merah (Allium ascalonicum. L) berumur lima minggu dapat di lihat pada Tabel 2 dan Tabel 3 di bawah ini:

Tabel 2 Rata-Rata Jumlah Daun Dan Tinggi Tanaman Bawang Merah Berumur Lima Minggu

\begin{tabular}{|c|c|c|c|c|c|}
\hline & \multirow{2}{*}{$\begin{array}{l}\text { Sum of } \\
\text { Squares }\end{array}$} & \multicolumn{4}{|c|}{ Mean } \\
\hline & & Df & Squar & $\mathrm{F}$ & Sig. \\
\hline $\begin{array}{l}\text { Between } \\
\text { Groups }\end{array}$ & 183.417 & 11 & 16.674 & $\begin{array}{r}120.05 \\
5\end{array}$ & $\begin{array}{l}5.000 \\
5\end{array}$ \\
\hline $\begin{array}{l}\text { Within } \\
\text { Groups }\end{array}$ & 3.333 & 24 & .139 & & \\
\hline Total & 186.750 & 35 & & & \\
\hline
\end{tabular}

Tabel 3 : Ringkasan Hasil Uji Anova Data Tinggi Tanaman Bawang Merah Berumur Lima Minggu

\begin{tabular}{lccccc}
\hline & $\begin{array}{c}\text { Sum of } \\
\text { Squares }\end{array}$ & & \multicolumn{2}{c}{ Mean } & \\
& Df & Squar & F & Sig. \\
\hline $\begin{array}{l}\text { Between } \\
\text { Groups }\end{array}$ & 249.667 & 11 & 22.697 & 163.41 .000 \\
Within & & & & & 8 \\
Groups & & & & & \\
\hline Total & 253.000 & 35 & & \\
\hline
\end{tabular}

Hasil uji Anova terhadap jumlah daun tanaman bawang merah (Allium ascalonicum. L) ratarata pada umur lima minggu menunjukan nilai $F$ hitung sebesar 120.055 dengan nilai signifikasi sebesar 0.001 , nilai signifikan tersebut menunjukan nilai yang kurang dari 0.05 sedangkan nilai $\mathrm{F}$ hitung terhadap tinggi tanaman sebesar 163.418 dengan nilai sinifikasi sebesar 0.001 , nilai signifikan tersebut menunjukan nilai yang kurang dari 0.05 sehingga dapat diketahui bahwa 


\section{Indigenous Biologi \\ Jurnal pendidikan dan Sains Biologi \\ Volume 1(3) 2018 (24-33)}

pemberian pupuk NPK dan Limbah cair tahu berpengaruh terhadap jumlah daun dan tinggi tanaman bawang merah (Allium ascalonicum $\mathrm{L})$.

Jumlah daun terbanyak sampai berumur 28 HST dihasilkan oleh perlakuan kombinasi pupuk NPK dan Limbah Cair Tahu yakni perlakuan P1 sebanyak 22 helai , P2 sebanyak 27 helai dan P3 sebanyak 22 helai dan pada P5, P9, P6, P10 dan P11 tidak berbeda nyata, sedangkan P1 sampai dengan P11 berbeda nyata dengan kontrol yakni rata-rata jumlah daun 18 helai. Adanya pengaruh aplikasi pupuk NPK limbah cair tahu terhadap jumlah daun bawang merah (Allium ascalonicum $\mathrm{L}$ ) dapat dilihat perbedaan antara kombinasi pupuk NPK dan limbah cair tahu ( perlakuan P1, P2, dan P3 ) dengan tanaman pada perlakuan Pupuk NPK ( perlakuan P4, P5, P6 dan P7 ) dan perlakuan limbah cair tahu ( perlakuan P8, P9, P10 dan an P11) di bandingkan dengan Kontrol. Lebih banyaknya jumlah daun tanaman tersebut diakibatkan oleh ketersediaan unsur hara yang lebih tinggi. Hal tersebut diikuti pula oleh tingginya penyerapan unsur hara oleh tanaman bawang merah.

Menurut Hardjono (2003) dalam Saputra E.P (2016) menyatakan bahwa pemakaian pupuk majemuk NPK akan memberikan suplai unsur N, P dan $\mathrm{K}$ yang seimbang dan akan membantu pertumbuhan tanaman. Lebih lanjut Fatha (2007) melaporkan bahwa limbah cair tahu mengandung bahan organik yaitu karbohidrat dengan kadar $0,11 \%$, protein dengan kadar $0,42 \%$, lemak dengan kadar $0,13 \%$, besi dengan kadar 4,55\%, fosfor dengan kadar 1,74\% serta air dengan kadar 98,8\%. Menurut Rosallina (2008) dalam Jong. Y (2016), menjelaskan bahwa limbah tahu memiliki kandungan organik tinggi serta apabila protein yang terkandung dalam limbah cair tahu diurai oleh mikroba tanah maka senyawa $\mathrm{N}$ dapat dilepaskan dan diserap oleh akar tanaman. Hakim (2009), menjelaskan bahwa nitrogen merupakan nutrien vital terpenting bagi tanaman. Tercukupinya kebutuhan akan nitrogen menjadi faktor yang paling berpengaruh dalam pertumbuhan dan perkembangan daun. Selanjutnya fakta dengan perlakuan terbaik yaitu pada perlakuan P2 dengan kosentrasi pupuk NPK 50\% (10g) + limbah cair tahu 50\% (50 ML) dapat meningkatkan pertumbuhan daun bawang merah ( Allium ascalonicum $L$ ) secara optimal. Penggunaan pupuk dan limbah yang kurang atau lebih rendah dari kosentrasi tersebut justru menyebabkan kurangnya optimal pertumbuhan. Seyowati (2001) yang menyebutkan bahwa konsentrasi lebih besar akan melebihi kebutuhan akan unsur hara N. Unsur hara N dalam jumlah yang berlebihan tidak akan lagi merangsang tanaman memberikan hasil yang lebih tinggi.

Rata-rata tinggi tanaman bawang merah sampai pada umur 5 minggu dihasilkan oleh perlakuan kombinasi pupuk NPK dan Limbah Cair Tahu yakni perlakuan P1, P2 dan P3 dengan rata-rata tinggi tanaman $34,66 \mathrm{~cm}, 35 \mathrm{~cm}$, dan $38,66 \mathrm{~cm}$ dan pada $P 7$ dan $P 11$ tidak berbeda nyata, sedangkan $\mathrm{P} 1$ sampai dengan $\mathrm{P} 11$ berbeda nyata dengan kontrol dengan rata-rata tinggi tanaman 26,66 cm. Hasil tertinggi dari perlakuan kombinasi pupuk NPK dan Limbah cair tahu terdapat pada perlakuan P2 dengan kosentrasi 50\% NPK dan 50\% limbah cair tahu. Adanya perbedaan pertumbuhan tanaman dpengaruhi oleh ketersediaan unsur hara yang di butuhkan. Menurut Fitriyah (2015) dalam Jong. Y (2016) limbah cair tahu kandungan N, P dan K. Besarnya unsur N, P dan K adalah N sebesar 164.9 ppm, P sebesar 15.66 ppm dan K sebesar 625 ppm. Lebih lanjut Eka Saputra, (2016), menyatakan bahwa pupuk majemuk NPK mengandung tiga unsur utama yaitu nitrogen, kalium dan fosfat. Adanya kandungan unsur hara tersebut menyebabkan penggunaan pupuk NPK dan limbah cair tahu dapat meningkatkan ketersediaan hara dalam media tanam sehingga menunjang pertumbuhan tanaman bawang merah ( Allium ascalonicum L ).

\section{Pengaruh pupuk NPK dan Limbah Tahu terhadap jumlah umbi dan diameter umbi bawang merah (Allium ascalonicum. L)}

Data Jumlah umbi dan diameter umbi bawang merah (Allium ascalonicum. L) setelah panen di sajikan pada tabel 4 di bawah ini: 
Tabel 4. Rata-Rata Jumlah Umbi Dan Diameter Umbi Bawang Merah Setelah Panen

\begin{tabular}{llll}
\hline Perlakuan & $\mathrm{N}$ & $\begin{array}{l}\text { Jumlah } \\
\text { Umbi }\end{array}$ & $\begin{array}{l}\text { Diameter } \\
\text { Umbi }\end{array}$ \\
\hline $\mathrm{K}$ & 3 & 4 & 5 \\
\hline $\mathrm{P} 1$ & 3 & 7 & 8,33 \\
\hline $\mathrm{P} 2$ & 3 & 10 & 10,66 \\
\hline $\mathrm{P} 3$ & 3 & 7 & 9 \\
\hline $\mathrm{P} 4$ & 3 & 5 & 6 \\
\hline $\mathrm{P} 5$ & 3 & 7 & 7,33 \\
\hline $\mathrm{P} 6$ & 3 & 7 & 7 \\
\hline $\mathrm{P} 7$ & 3 & 7 & 7,33 \\
\hline $\mathrm{P} 8$ & 3 & 5 & 6 \\
\hline $\mathrm{P} 9$ & 3 & 7 & 7,66 \\
\hline $\mathrm{P} 10$ & 3 & 7 & 7 \\
\hline $\mathrm{P} 11$ & 3 & 7 & 7 \\
\hline
\end{tabular}

Ringkasan Hasil uji Anova data jumlah umbi dan diameter umbi bawang merah (Allium ascalonicum. L) dapat di lihat pada Tabel 5 dan Tabel 6 dibawah ini:

Tabel 5 Ringkasan Hasil Uji Anova Data Jumlah umbi Bawang Merah

\begin{tabular}{lccccc}
\hline & $\begin{array}{c}\text { Sum of } \\
\text { Squares }\end{array}$ & Df & $\begin{array}{c}\text { Mean } \\
\text { Square }\end{array}$ & F & Sig. \\
\hline $\begin{array}{l}\text { Between } \\
\text { Groups }\end{array}$ & 72.750 & 11 & 6.614 & 79.364 & .000 \\
$\begin{array}{l}\text { Within } \\
\text { Groups }\end{array}$ & 2.000 & 24 & .083 & & \\
\hline Total & & & & & \\
\hline
\end{tabular}

Tabel 6 Ringkasan Hasil Uji Anova Data Diameter Umbi Bawang Merah

\begin{tabular}{llllll}
\hline & $\begin{array}{l}\text { Sum of } \\
\text { Squares }\end{array}$ & & $\begin{array}{l}\text { Mean } \\
\text { Square }\end{array}$ & & \\
\hline $\begin{array}{l}\text { Between } \\
\text { Groups }\end{array}$ & 77.889 & 11 & 7.081 & 50.982 & .000 \\
$\begin{array}{l}\text { Within } \\
\text { Groups }\end{array}$ & 3.333 & 24 & .139 & & \\
\hline Total & 81.222 & 35 & & & \\
\hline
\end{tabular}

Hasil uji Anova terhadap jumlah umbi bawang merah (Allium ascalonicum. L) setelah dipanen menunjukan nilai $F$ hitung sebesar 79.364 dengan nilai sinifikasi sebesar 0.001 , nilai signifikan tersebut menunjukan nilai yang kurang dari 0.05. sedangkan hasil uji anova terhadap diameter umbi bawang merah nilai $F$ hitung sebesar 50.982 dengan nilai sinifikasi sebesar 0.001 , nilai signifikan tersebut menunjukan nilai yang kurang dari 0.05 , sehingga dapat diketahui bahwa pemberian pupuk NPK dan Limbah cair tahu berpengaruh terhadap jumlah umbi dan diameter umbi bawang merah (Allium ascalonicum $\mathrm{L}$ ). Rata-rata jumlah umbi per-rumpun tanaman bawang merah (Allium ascalonicum. L) terlihat bahwa rata-rata jumlah umbi terbanyak terdapat pada 


\section{Indigenous Biologi \\ Jurnal pendidikan dan Sains Biologi \\ Volume 1(3) 2018 (24-33)}

perlakuan P2 yaitu dengan jumlah umbi sebanyak 10 umbi. Artinya bahwa P2 pengaruh nyata dengan perlakuan $\mathrm{P} 1$, p3 sampai $\mathrm{P} 11$. Sedangkan perlakuan $\mathrm{P} 1$ sampai dengan $\mathrm{P} 11$ pengaruh nyata dibanding dengan kontrol dimana pada Kontrol rata-rata jumlah umbinya sebanyak 4 umbi. Sedangkan diameter umbi terbesar tanaman bawang merah terlihat bahwa rata-rata diameter umbi terbesar (TB) terdapat pada perlakuan P1, P2 dan P3 yaitu dengan diameter umbi 8,33 cm, $9,00 \mathrm{~cm}$ dan $10.66 \mathrm{~cm}$.sedangkan perlakuan Perlakuan P1 sampai dengan P11 pengaruh nyata dibanding dengan kontrol dimana pada Kontrol rata-rata diameter umbinya $5,00 \mathrm{~cm}$. Adanya perbedaan pengaruh pemberian pupuk NPK dan limbah cair tahu terhadap diameter umbi bawang merah dipengaruhi oleh ketersediaan unsur hara yang terkandung didalamnya.

Selanjutnya fakta dengan perlakuan P2 (50\% pupuk NPK $+50 \%$ limbah cair tahu) dapat meningkatkan diameter umbi bawang merah. Penggunaan pupuk NPK maupun limbah cair tahu yang lebih rendah dan lebih tinggi dari kosentrasi tersebut justru memberi hasil yang kurang optimal. Menurut Jong Y. (2016) menjelaskan bahwa penggunaan limbah cair tahu yang lebih rendah dan lebih tinggi kosentrasinya akan menunjukan hasil yang kurang optimal. Lebih lanjut setyowati (2001) menjelaskan bahwa kosentrasi lebih besar akan akan melebihi kebutuhan akan unsur hara nitrogen. Unsur hara $\mathrm{N}$ dalam jumlah yang lebih tinggi tidak akan lagi memberikan hasil yang lebih tinggi. Umbi adalah bagian tanaman yang berfungsi sebagai tempat untuk menyimpan makanan. Umbi lapis bawang merah merupakan modifikasi dari pelepah daun yang tersusun rapat membentuk umbi. Semakin banyak daunnya maka pelepah daunnya juga semakin banyak sehingga modifikasi pelepah daun menjadi lapisan penyusun umbi juga akan semakin banyak.

\section{Simpulan}

\section{PENUTUP}

Pupuk majemuk NPK dan Limbah Cair Tahu berpengaruh terhadap pertumbuhan jumlah daun dan tinggi tanaman tanaman dan diameter umbi bawang merah (Allium ascalonicum $\mathrm{L}$ ). Konsentrasi perlakuan yang dapat meningkatkan parameter pertumbuhan jumlah daun, tinggi tanaman dan diameter umbi dari bawang merah (Allium ascalonicum. $\mathrm{L}$ ) yaitu pada konsentrasi P1 (25\% pupuk NPK + 75\% limbah cair tahu), P2 ( $50 \%$ pupuk NPK + 50\% limbah cair tahu) dan P3(75\% pupuk NPK $+25 \%$ limbah cair tahu). Sedangkan konsentrasi perlakuan yang paling optimal dalam meningkatkan parameter jumlah umbi dari bawang merah (Allium ascalonicum. L) yaitu pada konsentrasi P2 (50\% pupuk NPK $+50 \%$ limbah cair tahu). Pengaruh pemberian pupuk NPK dan limbah cair tahu dengan kosentrasi lebih rendah dan lebih tinggi dapat menunjukan hasil yang kurang optimal.

\section{Saran}

1. Perlu dilakukan penelitian lanjutan mengenai konsentrasi air yang dibutuhkan oleh bawang merah

2. Perlu dilakukan penelitian lanjutan mengenai penggunaan limbah cair tahu pada jenis tanaman yang berbeda.

3. Perlu dilakuakan penelitian lanjutan untuk fermentasi limbah cair tahu menjadi pupuk bokasi cair.

\section{DAFTAR PUSTAKA}

Amelia, W 2015. Perbandingan Pemberian Variasi Kosentrasi Pupuk Dari Limbah Cair Tahu Terhadap Pertumbuhan Tanaman Cabai Rawit (Capsicum Frutesces L.) Skripsi. Semarang: Jurusan pendidikan Biologi, Universitas Negeri Walisongo Semarang

Ariyanti L. 2011. Pemanfaatan umput laut sargosum Sp sebagai adsorben limbah cair industri rumah tangga perikanan. Skripsi. Depertemen teknologi hasil perairan fakultas perikanan dan ilmu kelautan Institut pertanian. Bogor. 
Bahri, S., 2006, "Pemanfaatan Tumbuhan Air (Azzola) untuk Pengolahan Limbah Cair Industri Tahu Di Lampung Tengah : Fakultas Matematika dan Ilmu Pengetahuan Alam, Universitas Lampung, Lampung.

Basmal J. 2009. Prospek Pemanfaatan Rumput Laut Sebagai Bahan Pupuk Organik. Jurnal Squalen Vol. 4 NDi Akses 18 Maret.

Fadilla, Z. 2010. Pengaruh Konsentrasi Cair Tahu terhadap Pertumbuhan Mikroalga Scendesmu sp. Skripsi. Jakarta: Progam Studi Biologi Fakultas Sains dan Teknologi Universitas Islam Negeri (UIN) Syarif Hidayatullah Jakarta. pdf. Diakses Pada Tanggal 21 Oktober 2015

Fitriyah, N.R. 2011. Studi Pemanfaatan Limbah Cair Tahu Untuk Pupuk Air Tanaman (Studi Kasus Pabrik Tahu Kenjaran). Skripsi. Surabaya: Jurusan Teknik Lingkungan Institut Teknologi Sepuluh November

Griffiths, G., Trueman, L., Crowther, T., Thomas, B. \& Smith, B. 2002. Onions-a global benefit to health. Phytotherapy Research 16(7): 603-615.

Handajani, Hany. 2006. Pemanfaatan Limbah Cair Tahu Sebagai Pupuk Alternatif Pada Kultur Mikroalga Spirullina Sp. Jurnal Protein Vol.13, No.2,: 188-193.

Hakim, mahirul, A. 2009 asupan nitrogen dan pupuk organik cair terhadap hasil dan kadar vitamin $C$ kelopak bunga rosela ( Hiasbiscus sabdariffa $L$ ), skripsi. Surakarta : fakultas pertanian universitas sebelas Maret.

Hidayat, A. \& Rosliani. 1996. Pengaruh pemupukan N, P dan K pada pertumbuhan dan produksi bawang merah kultur sumenep. Jurnal hort. 5 (5) 39-43

Istina. 2016. Peningkatan Produksi Bawang Merah Melalui Teknik Pemupukan NPK. Jurnal Agro Vol. III, No. 1, Juli 2016

Jong, Y 2016. Pengaruh Pemberian Limbah Cair Tahu Terhadap Pertumbuhan Vegetatif Terung Ungu (Solanum Melongena L.) di Kelurahan Oepura Kecamatan Maulafa Kota Kupang. Skripsi. Jurusan Biologi Fakultas

Lubis, E. Darmawati \& Hidayat M.A. 2013. Limbah cair tahu dan pemberian pupuk urea terhadap pertumbuhan dan pproduksi tanaman Kedelai (Glycine max L.(Merill). Medan: Fakultas Pertanian Universitas Muhammadiyah Sumatera Utara

Nurhasan \& Pramudyanto. 1991. Penanganan Air Limbah Tahu,Yayasan Bina Karya Lestari : Semarang

Rukmana R. 1994. Bawang Merah Budidaya dan Pengolahan Pacapanen. Penerbit Kanisius. Yogyakarta

Silfa, N. Wiwin \& Santoso, M. 2015. Pengaruh Aplikasi Biourin Dan Pupuk Terhadap Pertumbuhan Dan Hasil Tanaman Bawang Merah (Allium ascalonicum L.) Jurnal Produksi Tanaman, Volume 3, Nomor 6, September 2015, hlm. 457 - 463

Setiawan, A, Rosita S, \& Simanungkalit, T. 2015. Pertumbuhan dan Produksi Bawang Merah (Allium ascalonicumL.) Terhadap Dosis Limbah Cair Pabrik Kelapa Sawit dan Tipe Pemotongan Umbi. Jurnal Online Agroekoteknologi . ISSN No. 2337- 6597 Vol.3, No.1 : $340-349$

Suwandi ,Sopha \& Yufdy. 2015. Efektivitas Pengelolaan Pupuk Organik, NPK, dan Pupuk Hayati terhadap Pertumbuhan dan Hasil Bawang Merah. Jurnal. Hort. Vol. 25 No. 3, September 2015: 208-221

Setyowati, E. 2001. Tugas Akhir Ujian Pemanfaatan Unsur N Dan P Dalam Limbah Tahu Sebagai Pupuk Pada Tanaman Padi. Tugas Akhir. Surabaya : Teknik Lingkungan, FSTP, Institut Teknologi Surabaya

Saputra, E. P. 2016. Respons Tanaman Bawang Merah (Allium Ascalonicum L.) Akibat Aplikasi Pupuk Hayati Dan Pupuk Majemuk NPK Dengan Berbagai Dosis. Skripsi. Fakultas Pertanian Universitas Lampung Bandar Lampung 
Sosrosoedjirdjo, 2004. Ilmu Memupuk.Jilid I.CV.Yasaguna. Jakarta.

Sri Ariani B.P Nana, Zuchrotus Salamah. 2014. Pertumbuhan Tanaman Bawang Merah (Allium cepa L.) dengan Penyiraman Air Kelapa (Cocos nucifera L.) Sebagai Sumber Belajar Biologi SMA Kelas XII. JUPEMASI-PBIO Vol. 1 No. 1 Tahun 2014, ISSN: 2407 -1269 | Halaman 82-86

Willy, A. T, Rosita,S \& Ferry E. S.2014. Pertumbuhan Dan Produksi Bawang 10

Merah (Allium Ascalonicum L.) Dengan Pemberian Pupuk Hayati Pada Berbagai Media Tanam. Jurnal Online Agroekoteknologi . ISSN No. 2337- 6597, Vol.2, No.2 : 825 - 836

Wibowo, S. 2001. Budidaya Bawang ( Bawang Putih, Merah dan Bombay). Penebar Swadaya. Jakarta 